\title{
MEMBANGUN SISTEM INFORMASI PENDAFTARAN NIKAH DI KANTOR URUSAN AGAMA GAMPING BERBASIS WEB
}

\author{
Mario Soemyrat Sengga Sae ${ }^{1}$, Titik Rahmawati ${ }^{2}$, Landung Sudarmana ${ }^{3}$ \\ 1,2,3 Program Studi Informatika \\ Universitas Jenderal Achmad Yani Yogyakarta \\ E-mail : willerkasani@gmail.com
}

\begin{abstract}
ABSTRAK
Pendaftaran nikah di Kantor Urusan Agama Kecamatan Gamping, calon pengantin mendaftarkan pernikahan dengan mendatangi kantor dengan menyerahkan dokumen persyaratan nikah. Pencatatan dan pengelolaan dokumen administrasi pernikahan dilakukan oleh pegawai. Setelah proses pencatatan nikah selesai maka pegawai akan melakukan penjadwalan ijab kabul. Proses terakhir yaitu pembuatan laporan pernikahan seperti buku nikah dan lainnya sehingga di saat pandemi covid perlu adanya sistem yang dapat mengolah data pendaftaran nikah berbasis online. Sistem dibuat menggunakan bahasa pemrograman PHP dan MySQL sebagai basis data. Sistem ini juga diintegrasikan dengan framework CSS Bootstrap sehingga desain tampilannya akan bersifat responsif. Sistem ini dibangun menggunakan metode waterfall. Hasil penelitian adalah membangun sistem informasi yang dapat membantu pegawai mengolah data pendaftaran dan memberikan informasi mengenai jadwal kepada calon pengantin. Sistem ini memiliki beberapa fitur diantaranya pendaftaran nikah, unggah berkas dokumen persyaratan, jadwal nikah dan laporan pendaftaran nikah.
\end{abstract}

Kata kunci : Sistem Informasi, Kantor Urusan Agama, Jadwal, Pendaftaran Nikah

\begin{abstract}
Marriage registration at the Gamping District Religious Affairs Office, the bride and groom register their marriage by visiting the office by submitting marriage requirements documents. The recording and management of marriage administrative documents is carried out by employees. After the marriage registration process is complete, the employee will schedule the Ijab Kabul. The last process is making marriage reports such as marriage books and others so that during the covid pandemic there is a need for a system that can process online-based marriage registration data. The system is made using the PHP and MySQL programming languages as databases. This system is also integrated with the CSS Bootstrap framework so that the display design will be responsive. This system was built using the waterfall method. The result of the research is to build an information system that can help employees process registration data and provide information about the schedule to the bride and groom. This system has several features including marriage registration, uploading required document files, marriage schedules and marriage registration reports.
\end{abstract}

Keywords : Information System, Religious Affairs Office, Schedule, Marriage registration 


\section{PENDAHULUAN}

Kantor Urusan Agama (KUA) merupakan instansi lembaga yang bernaung di bawah Kementerian Agama Republik Indonesia dan melaksanakan tugas berdasarkan Peraturan Pemerintah, baik undang-undang pernikahan maupun Peraturan Menteri Agama. Instansi ini merupakan salah satu lembaga pencatatan pernikahan yang bertugas mendaftarkan dan mengurus kelengkapan administrasi pernikahan [2]. KUA merupakan instansi yang sedang mengembangkan potensi para pegawai administrasinya di dalam bidang pengolahan data dan pelayanan administrasi secara efektif dari segi keakuratan, ketepatan dan relevansi terutama dalam pencatatan pernikahan.

KUA Kecamatan Gamping merupakan salah satu instansi yang pemanfaatan teknologi informasinya dalam hal proses pendaftaran nikah masih terbilang kurang karena penyampaian informasi persyaratan pernikahan dan informasi lainnya hanya diumumkan di instansinya dengan cara menempelkan informasi di papan pengumuman. Proses pendaftaran nikah yaitu calon pengantin mendatangi kantor untuk mendaftarkan pernikahan. Calon pengantin diminta untuk melakukan penyerahan dokumen persyaratan nikah. Pencatatan dan pengelolaan dokumen administrasi pernikahan oleh pegawai. Setelah proses pencatatan nikah selesai maka pegawai akan melakukan penjadwalan ijab kabul. Proses terakhir yaitu pembuatan laporan pernikahan seperti buku nikah dan lainnya.

Semua proses di atas dilakukan dengan cara mendatangi kantor dan mengisikan formulir pendaftaran serta melengkapi berkas dokumen persyaratan pernikahan. Ini menjadi masalah karena pandemi Covid-19 telah menyebar secara luas, mengetahui kondisi tersebut pendaftaran pernikahan menjadi kurang maksimal. Permasalahan lainnya, pegawai masih mencatat dan membuat laporan pendaftaran nikah secara manual yaitu dengan mencatat di buku arsip serta menggunakan komputer. Penggunaan komputer hanya sebatas untuk pencatatan data karena hanya menggunakan aplikasi Microsoft Excel sehingga tidak semua pegawai dapat mengakses data tersebut yang menyebabkan pendataan tidak terintegrasi dengan baik. Hambatan atau kendala saat pembuatan laporan terjadi karena berkas tidak tersimpan di satu bagian saja, akibatnya pihak administrasi mengalami keterlambatan dan mengalami kesalahan saat pembuatan laporan karena berkas yang tersebar.

Penelitian-penelitian sebelumnya telah dilakukan dengan tujuan untuk memberikan kemudahan bagi calon pengantin dan pihak KUA dalam melaksanakan pendaftaran nikah dengan membuat sebuah aplikasi [1], [3], [5]. Adapun perbedaan dengan penelitian sebelumnya adalah adanya tambahan aktor penghulu, fitur pendaftaran nikah, unggah berkas dokumen persyaratan, jadwal nikah dan laporan pendaftaran nikah.

Berdasarkan permasalahan di atas, diusulkan sistem yang dapat mengatasi masalah pencatatan dalam proses pendaftaran nikah dengan membangun sistem informasi pendaftaran nikah berbasis web. Sistem ini bermanfaat untuk mengolah data pendaftaran dan memudahkan masyarakat yang akan melakukan pendaftaran nikah. Sistem ini terdiri dari 4 aktor yaitu admin, kepala KUA, penghulu dan calon pengantin.

\section{TUJUAN DAN MANFAAT PENELITIAN}

Tujuan penelitian adalah membangun sistem informasi pendaftaran nikah yang dapat membantu masyarakat dalam melakukan pendaftaran nikah dan membantu pihak KUA dalam mengelola maupun mencari data pendaftaran pernikahan berbasis online, dan manfaat penelitian adalah:

a. Membantu masyarakat yang akan melakukan pendaftaran nikah secara online sehingga dapat mempersingkat waktu

b. Bermanfaat bagi pihak KUA untuk mengelola data pendaftaran

c. Proses perncarian data oleh pihak KUA menjadi lebih cepat 


\section{BAHAN DAN ALAT PENELITIAN}

Bahan berupa interview dengan pihak KUA yang berkaitan dengan proses bisnis sistem, dan sumber lain berupa jurnal. Alat yang digunakan berupa seperangkat laptop berkoneksi internet dengan sistem operasi: windows 10, local server: xampp 5.6.36, webserver: apache 2.4, database: MySQL 5.5.3, text editor : notepad++ versi 8.1, bahasa pemrograman : PHP 7.3, framework CSS: bootstrap versi 4.

\section{METODOLOGI PENELITIAN}

Perancangan sistem informasi menggunakan model waterfall [4], dengan beberapa tahap proses yaitu:

a. Analisis kebutuhan, yang menganalisis proses pendaftaran nikah di KUA, dan menganalisis keinginan dan kebutuhan pengguna terdiri admin, kepala KUA, penghulu dan masyarakat terhadap sistem yang akan dikembangkan.

b. Parancangan sistem, terdiri perancangan input dan output, perancangan database, perancangan proses dan interface.

c. Coding dan testing (implementasi), membuat program menggunakan PHP dan MySQL.

d. Penerapan, tahapan final dalam pembuatan sistem.

\section{PERANCANGAN}

Perancangan sistem menggunakan UML yang terdiri dari use case diagram, activity diagram, Entitty Relationship Diagram (ERD).

a. Perancangan Sistem

Interaksi aktor yang terdiri admin, kepala KUA, penghulu dan calon pengantin dalam perancangan sistem [7] dapat dilihat pada gambar 1.

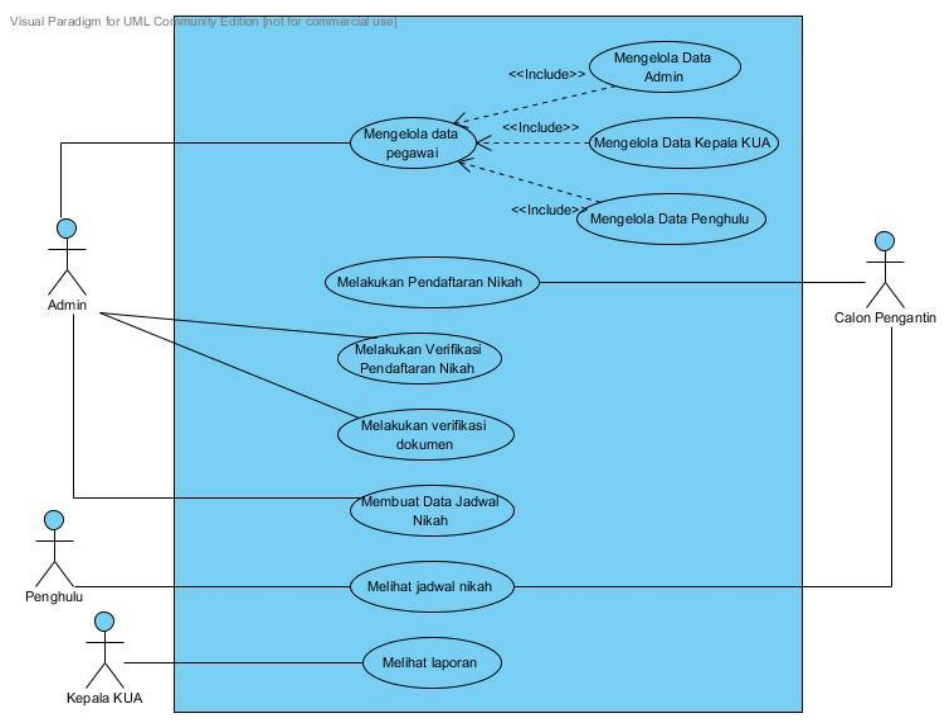

Gambar 1. Use Case Diagram Pendaftaran Nikah

Aktor admin mengelola data pengguna, memverifikasi pendaftaran dan mengolah jadwal nikah, aktor penghulu menampilkan jadwal pernikahan, aktor calon pengantin mendaftarkan pernikahan dan menerima jadwal nikah, dan aktor kepala KUA melihat laporan pendaftaran nikah.

b. Perancangan hubungan antar entitas

Perancangan hubungan antar entitas dalam sistem dapat dilihat pada gambar 2. 


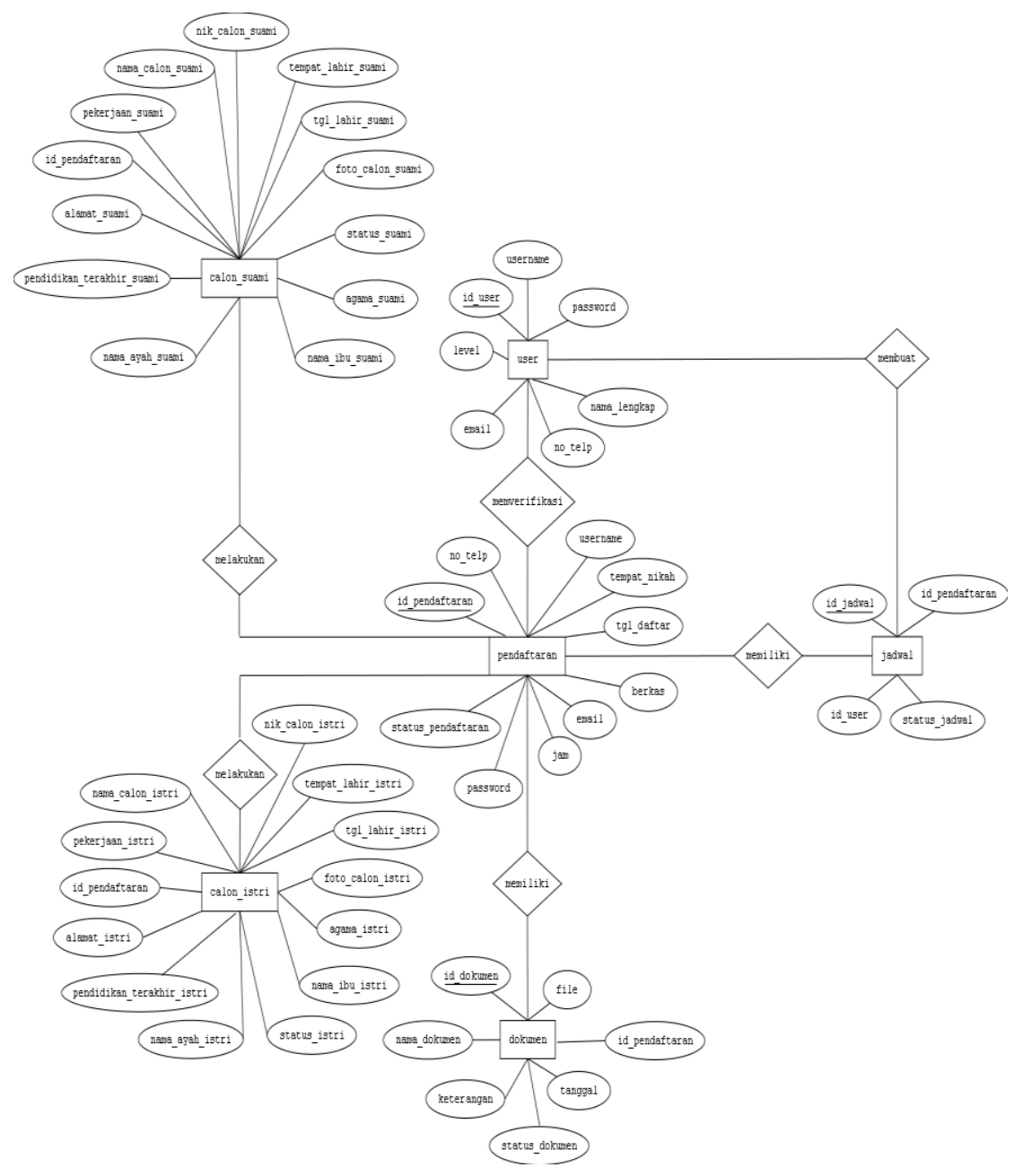

Gambar 2. ERD Pendaftaran Nikah

Pada gambar diatas terdapat entitas user, entitas pendaftaran, entitas calon suami, entitas calon istri, entitas dokumen dan jadwal.

c. Perancangan relasi antar tabel

Rancangan relasi tabel ditunjukkan pada pada gambar 3.

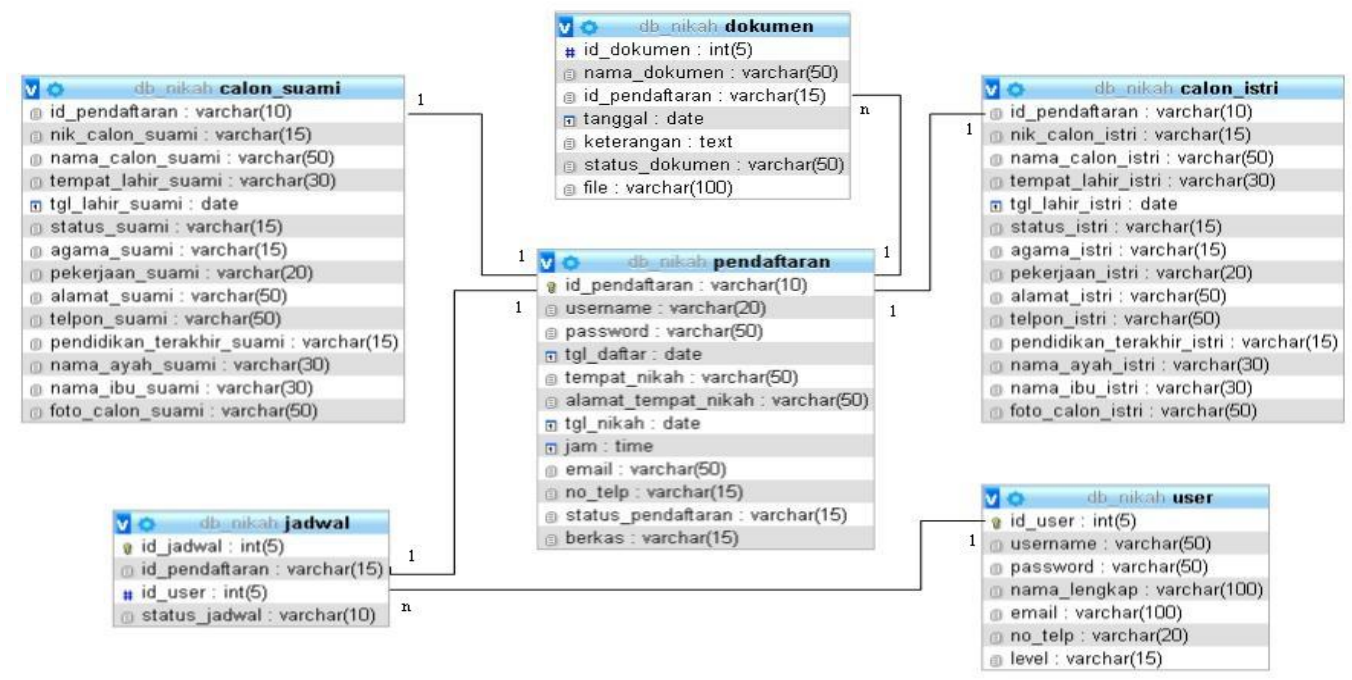

Gambar 3. Relasi Antar Tabel Pendaftaran Nikah 


\section{HASIL DAN PEMBAHASAN}

Hasil uji coba telah dilakukan, sistem aplikasi telah berfungsi dengan semestinya, dan hasil implementasi penelitian sebagai berikut:

a. Implementasi desain interface

Beberapa hasil desain interface antara lain:

1) Home publik

berisi informasi mengenai data persyaratan pendaftaran pernikahan, sehingga calon pengantin dapat langsung melihat informasi seperti form pendaftaran pendaftaran dan syarat pendaftaran yang ditunjukkan pada gambar 4 .

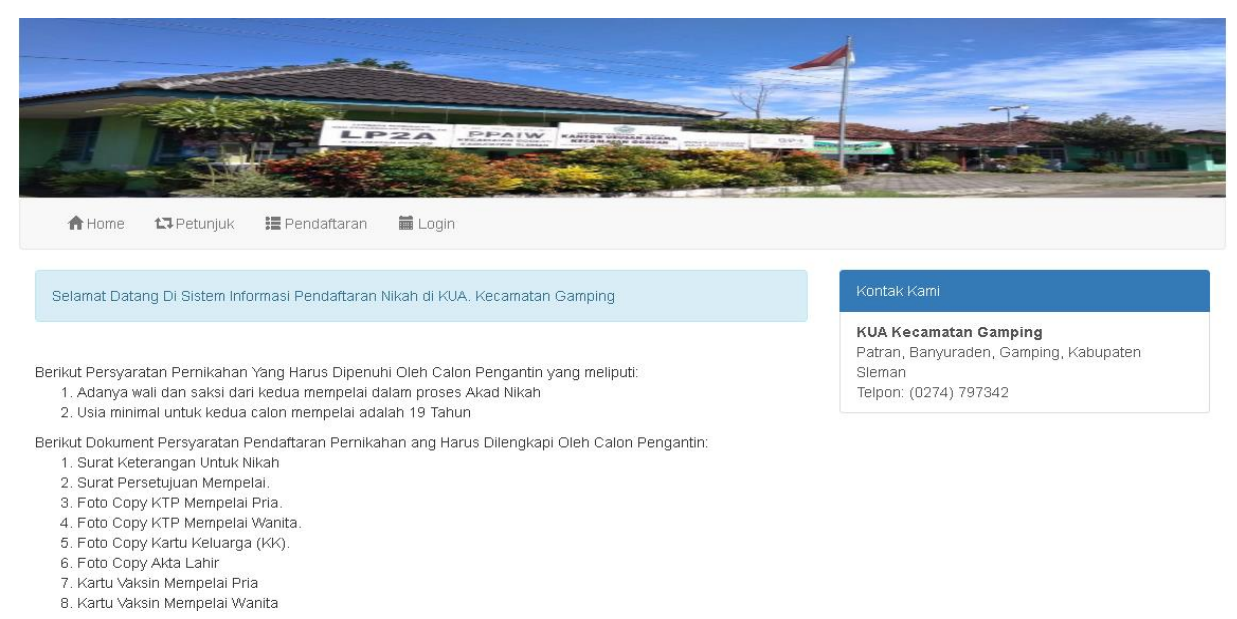

2) Login pengguna

Gambar 4. Halaman Publik

Calon pengantin yang sudah terdaftar dapat login ke sistem, dan tampilan dapat dilihat pada gambar 5 .

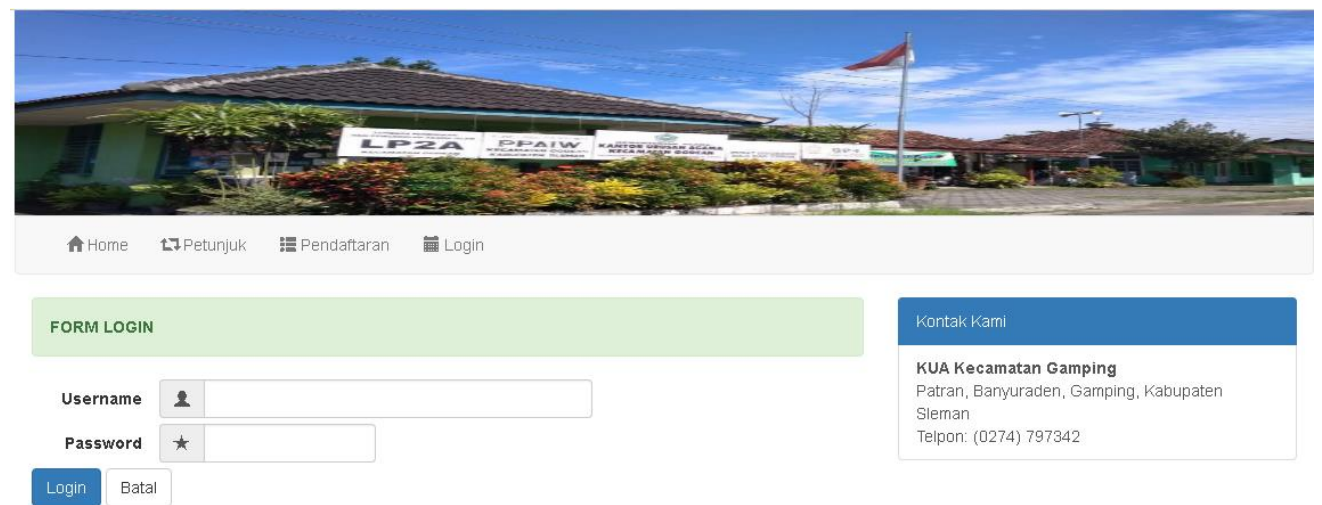

3) Pendaftaran menikah

Gambar 5. Form Login Pengguna

Halaman pendaftaran nikah digunakan calon pengantin untuk mendaftakan pernikahannya yang tampilannya ditunjukkan pada gambar 6 . 


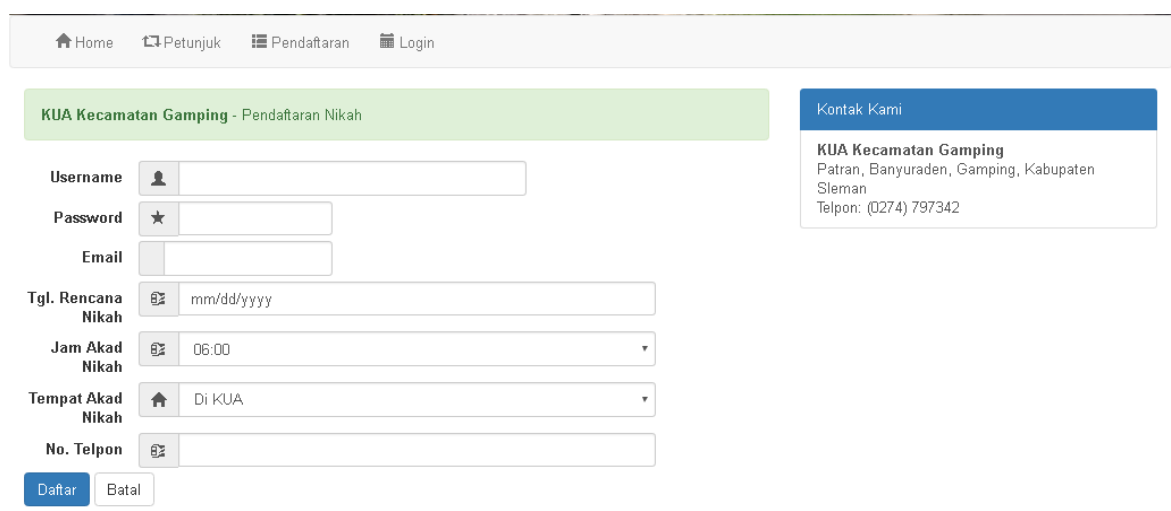

Gambar 6. Pendaftaran Menikah

4) Halaman dokumen pendaftaran

Form dokumen berisi persyaratan dokumen yang harus dipenuhi calon pengantin, dan diisi secara lengkap untuk memudahkan petugas dalam memverifikasi data, dan tampilan ditunjukkan pada gambar 7 .

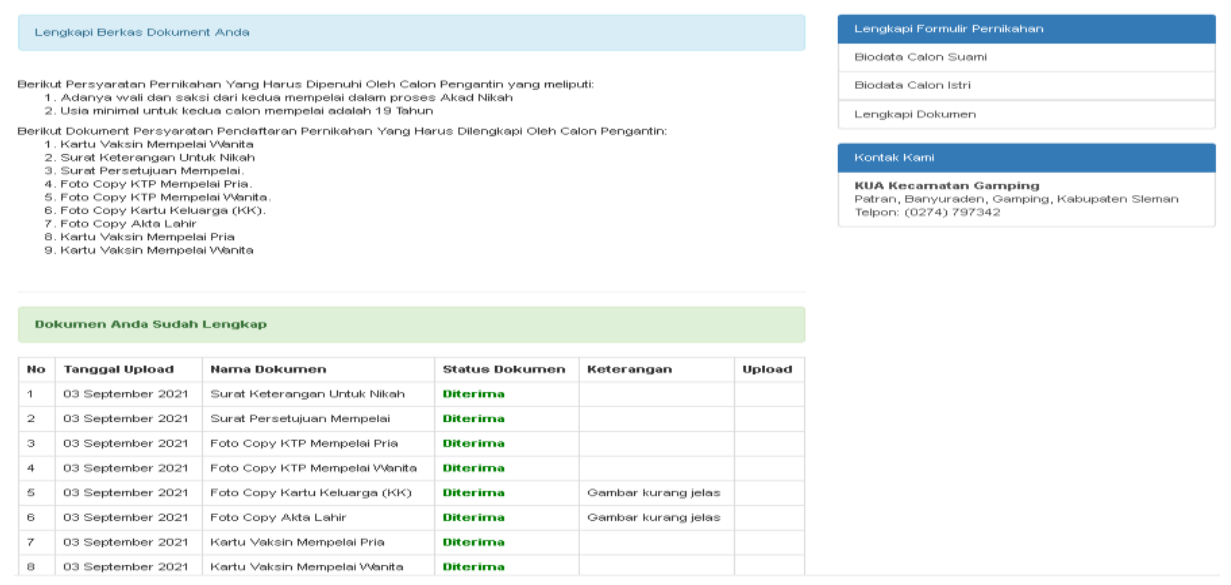

Gambar 7. Dokumen Pendaftaran

5) Halaman laporan

Halaman ini digunakan admin untuk menampilan laporan data pendaftaran nikah yang berisi informasi nomor pendaftaran, waktu dan tempat rencana akad nikah, email dan nomor telepon pengantin, dan hasil cetak laporan pendaftaran pernikahan ditunjukkan pada gambar 8 .

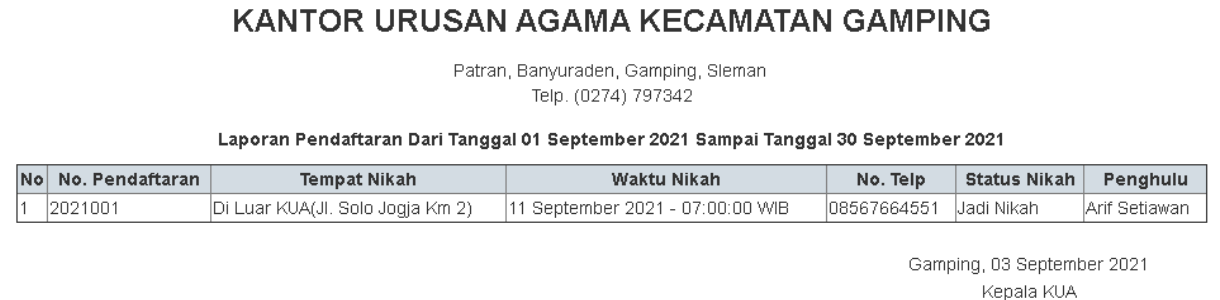

(Rudi Nugroho)

b. Pembahasan

Gambar 8. Halaman laporan

Sistem informasi pendaftaran nikah berbasis web ini dibangun menggunakan template Bootstrap dan bahasa pemrograman web yaitu PHP dan MySQL sebagai database 
untuk menyimpan data. Sistem ini terdiri dari 4 pengguna yaitu admin, kepala KUA, penghulu dan calon pengantin yang masing-masing mempunyai hak akses sendirisendiri. Sistem ini memiliki beberapa fitur diantaranya pendaftaran nikah, unggah berkas dokumen persyaratan, jadwal nikah dan laporan pendaftaran nikah serta memiliki kekurangan seperti belum adanya fitur notifikasi jadwal pernikahan melalui pesan whatsapp dan fitur upload data untuk saksi pernikahan.

\section{KESIMPULAN}

Sistem aplikasi ini memiliki fitur meliputi pendaftaran nikah, dan unggah berkas dokumen persyaratan secara online, jadwal pernikahan dan laporan pendaftaran nikah, dan dapat membantu pegawai dalam mengelola data pendaftaran nikah di KUA secara online, serta membantu calon pengantin dalam melakukan pendaftaran administrasi pernikahan secara online.

\section{DAFTAR PUSTAKA}

[1] Dahlan, U.I, 2020, Sistem Informasi Pendaftaran Nikah Kecamatan Selogiri Berbasis Web, Surakarta : Universitas Duta Bangsa.

[2] Djubaidah, N, 2020, Pencatatan Perkawinan \& Perkawinan Tidak Dicatat, Jakarta : Sinar Grafika.

[3] Oktaviani, I, 2019, Perancangan Sistem Informasi Pendaftaran Nikah Berbasis Online di KUA Kecamatan Cikelet, Garut : Sekolah Tinggi Teknologi Garut.

[4] Pressman, R.S, Maxim, B.R, 2019, Software Engineering: A Practitiner's Approach, Ninth Edition, USA : Mc Graw Hill.

[6] Rahayu, S, 2019, Merancang Sistem Informasi Pendaftaran Nikah Pada KUA Dengan Object Oriented Methodology, Tangerang : STMIK Raharja Tangerang.

[7] Sae, M.S.S, 2021, Sistem Informasi Pendaftaran Nikah Berbasis Web di Kantor Urusan Agama Kecamatan Gamping, Yogyakarta : UNJAYA Yogyakarta. 